\title{
Appreciative Inquiry Analysis Through SOAR Approach In The Lens Of Shariah In Facing Industry 4.0 On Indonesia's Islamic Banking
}

\author{
Zulfikar \\ FDepartment Syariah And Economics Academy Of Islamic Studies \\ University Of Malaya, Malaysia
}

\begin{abstract}
The research I conducted looked at how the impact of the industrial revolution 4.0 on the Islamic banking sector. In this case, I took a SOAR analysis approach (strengths, opportunities, aspirations and results), in contrast to the SWOT analysis, SOAR analysis resembled more at the advantages and opportunities of Islamic banking in achieving progress not only the world but also the hereafter. The SOAR analysis that I did combines with Sharia principles that will realize as in digital financing products and internet banking. The Sharia Supervisory Board and DSN-MUI are among the regulators making sharia banking stronger and recognized. Virtually a usury-free bank and towards the benefit of the Ummah both in the world and in the hereafter. The different method I use is a qualitative method by viewing at and analyzing the research object to be examined.
\end{abstract}

Keywords : Industrial revolution 4.0; Analysis SOAR; Islamic Banking; Shariah

\begin{abstract}
Abstrak:
Penelitian ini bertujuan untuk melihat bagaimana dampak revolusi industri 4.0 terhadap sektor perbankan syariah. Dalam hal ini, pendekatan yang digunakan adalah analisis SOAR (kekuatan, peluang, aspirasi dan hasil), berbeda dengan analisis SWOT, analisis SOAR lebih menyerupai keunggulan dan peluang perbankan syariah dalam mencapai kemajuan tidak hanya dunia tetapi juga akhirat. . Analisis SOAR dilakukan dengan menggabungkan prinsip Syariah yang akan direalisasikan seperti pada produk pembiayaan digital dan internet banking. Dewan Pengawas Syariah dan DSN-MUI merupakan salah satu regulator yang menjadikan perbankan syariah semakin kuat dan diakui. Praktis bank yang bebas riba dan menuju kemaslahatan umat baik di dunia maupun di akhirat. Metode lain yang digunakan adalah metode kualitatif dengan melihat dan menganalisis objek penelitian yang akan diteliti.
\end{abstract}

Kata Kunci : Revolusi Industri 4.0; Analisis SOAR; Perbankan Syariah; Syariah 


\section{INTRODUCTION}

The sharia financial industry in Indonesia is experiencing quite good development. The development of the sharia banking industry influenced by various factors, namely internal factors such as Human Resources (HR), funding, good corporate governance, and external factors such as economic growth and national and international sharia institutional infrastructure. One of the sharia institutional infrastructures at the national level that drives the growth of sharia banks is the Financial Services Authority (OJK). OJK continues to encourage and direct Islamic banks towards a healthy, sustainable, and positive contribution to the sharia banking industry in supporting quality economic development.

Significant immeasurable developments in the Islamic finance industry have a positive impact on the community's economy. The Islamic banking industry can make a substantial contribution in transforming the economy into productive, value-added and inclusive economic activities.

This strategic role continues driven by several policies that have been established by the competent authority. That is proven that one of OJK's policy priorities in 2016 in the banking sector, is to increase the contribution of Islamic banking to the national economy (the Financial Services Authority). Important agendas in the context of developing sharia banking in Indonesia continue to carried out in synergy between industry players and the government through the National Sharia Finance Committee (KNKS), OJK and cooperation of sharia banks in Indonesia.

The regularity realises the Islamic banking system in Indonesia the profit-sharing principle, advancing the value of togetherness, ukhuwah, and avoidance of speculative elements in every transaction. In carrying out business activities of Islamic banks based on sharia principles, economic democracy, and the law of prudence. Business activities carried out by Islamic banks may not contain elements of usury, maisir, gharar, haram, and wrongdoers (according to sharia principles), must include the values of justice, togetherness, equality and benefit (economic democracy). As an Islamic financial institution, Islamic banks have different roles and functions that are different from conventional banks. Islamic banks manage profit-oriented activities and social orientation. Islamic banks act as financial intermediaries in the form of transaction financing sale and purchase (debt financing), business financing (profit lost sharing), fee-based financing/ujrah. They have a social function as a container of zakat funds and benevolent loans/bailouts (qard and qard al-hasan).

With such a complex function, the Islamic bank confronted on various kinds of challenges. During competition and challenges, the Islamic banking industry can grow, with the ninth-largest asset growth in the world with assets of 35.6 billion USD in 2013 (Financial Services Authority 2017). To expand accurately, Islamic banks must have a principle for increasingly diverse product innovation and development. Different varieties of industries must be made by Islamic banking as an industry player to extend spread out to the community by combining additional product modifications following the FSA regulations and the MUI National Sharia Council fatwa.

Various fatwas have been issued by DSN-MUI to support the Islamic banking system. Before making a fatwa, Islamic banking will discuss with multiple parties, especially with the Sharia Supervisory Board and banking management. After obtaining approval from the Sharia Supervisory Board, it can then propose to DSN-MUI to make a fatwa regarding the contract used in sharia banking. Islamic Banking has done many analyzes to see the strengths, weaknesses, opportunities and threats (SWOT) for more advanced banking developments. In addition to the SWOT analysis conducted, it is also essential to use SOAR analysis (strengths, opportunities, aspirations and results). 
The Industrial Revolution 4.0 has transformed all aspects of social life, all sectors of industry and business have progressed from the Industrial Revolution 1.0 to the present, the Industrial Revolution 4.0, wholly distinguished as Industrial Revolution 4.0. Industrial revolution 4.0 is a massive change in various fields that make human performance and machine performance into activities that carried out concurrently based on meeting needs, economic development and technological development. Industrial Revolution, 4.0 not only changes in the technology sector but also in the others, are financial, legal and social.

A particular model that can take from the use of technology in the industrial domain is the auditing and making process, which is now effortlessly available to anyone and at any time. Aside from the role of technology in the industry, the advantages can also get by all levels of society. At present, information retrieval and exchange can be quickly done anytime and anywhere through the internet network. In industrial age 4.0, all sectors in the world struggled to create and innovate various fields of products. Particularly in the area of banking, Islamic banking also does not want to be defeated by multiple technologies that can use in developing a more significant business.

In facing the 4.0 era in the sharia banking sector, it is crucial to have the analysis wanted to achieve success in the world and the hereafter, which have enhanced the principal objectives of sharia banking. In addition to the interpretation that has used in general, that is the SWOT analysis, and different analyzes focus more on developing strengths and opportunities rather than problems, weaknesses and threats. That analysis generally regarded to as SOAR analysis. SOAR analysis needed in the banking sector, especially Islamic banking which has various challenges to be able to compete with conventional banking, joined with the emergence of the industrial revolution 4.0 which has changed many information technologies.

SOAR analysis is a new method when compared with SWOT analysis which is long and has ingrained in humans. However, SOAR appears in this era has shown and has provided many benefits. Within the SOAR framework, as many stakeholders as possible are involved, based on the integrity of its members. The issue of integrity is fundamental because stakeholders must be aware of the assumptions that are the basis of the drivers of the organization's leaders.

So I am interested in making a study of SOAR analysis during the industrial revolution 4.0 , and relating with the Islamic banking sector in Indonesia.

\section{METHOD}

The research that I use is a library research method and searching for data sources in online media with data analysis techniques using qualitative methods. Why do I use qualitative methods because I use this method to find information sharing that I will explain and analyze according to the field of study I am studying.

\section{RESULTS AND DISCUSSION}

This 4.0 industrial revolution disrupts all human activities in various fields of technology but also penetrates other areas such as economic, political and social. The industrial revolution 4.0 has introduced flexible mass production technology. The machine will operate with humans independently. Industry 4.0 used on interrelated factors, namely digitalization and economic interaction. That is simple techniques towards financial networks with sophisticated technologies, digitization of production and services and new market 
Appreciative Inquiry Analysis Through SOAR Approach In The Lens Of Shariah In Facing Industry 4.0 On Indonesia's Islamic Banking models. One of the characteristics of the industrial revolution 4.0 is artificial intelligence or often called Artificial Intelligence, one of which is the use of computerization and robots that aim to replace human labour into cheap, fast, effective, and efficient. Therefore the level of effectiveness and time efficiency can be increased where time is vital in the industrial world. Besides the benefits of the industrial revolution 4.0 in the industrial field, the benefits of technology can additionally sense by everyone. At present access to information is very easy and can be done anytime and anywhere with an internet network.

Differences transpire forward amidst human capabilities within the provided start to innovation. Innovative products and different methods are formed together with technical improvement. Every period always gives birth to tremendous needs-oriented and innovation benefit of life. Innovation is the key to success in the industry. The industrial revolution characterised by a change in lifestyle and the mindset of the people and the state. The Industrial Revolution insistence colour the pattern of public life, both in the economic, sociocultural and political fields. People are starting to change their ways to think that from the agrarian sector slipped towards the industry. The industrial revolution that transpired the first time in Britain was economic. The style of the British economy, which was initially agrarian turned into a trade. At that time, the method of making goods was also still conventional, namely relying on human and animal power. The manufacture of products is also always being done in homes, not yet done in factories.

The industrial revolution is a significant change in the way humans process resources and produces goods. The industrial revolution was a phenomenon that occurred between 1750 - 1850. At that time, there were large-scale changes in agriculture, manufacturing, mining, transportation, and technology. These changes have an impact on the social, economic, and cultural conditions in the world.

Figure 1.0: Development of the Industrial Revolution from 1.0 to 4.0

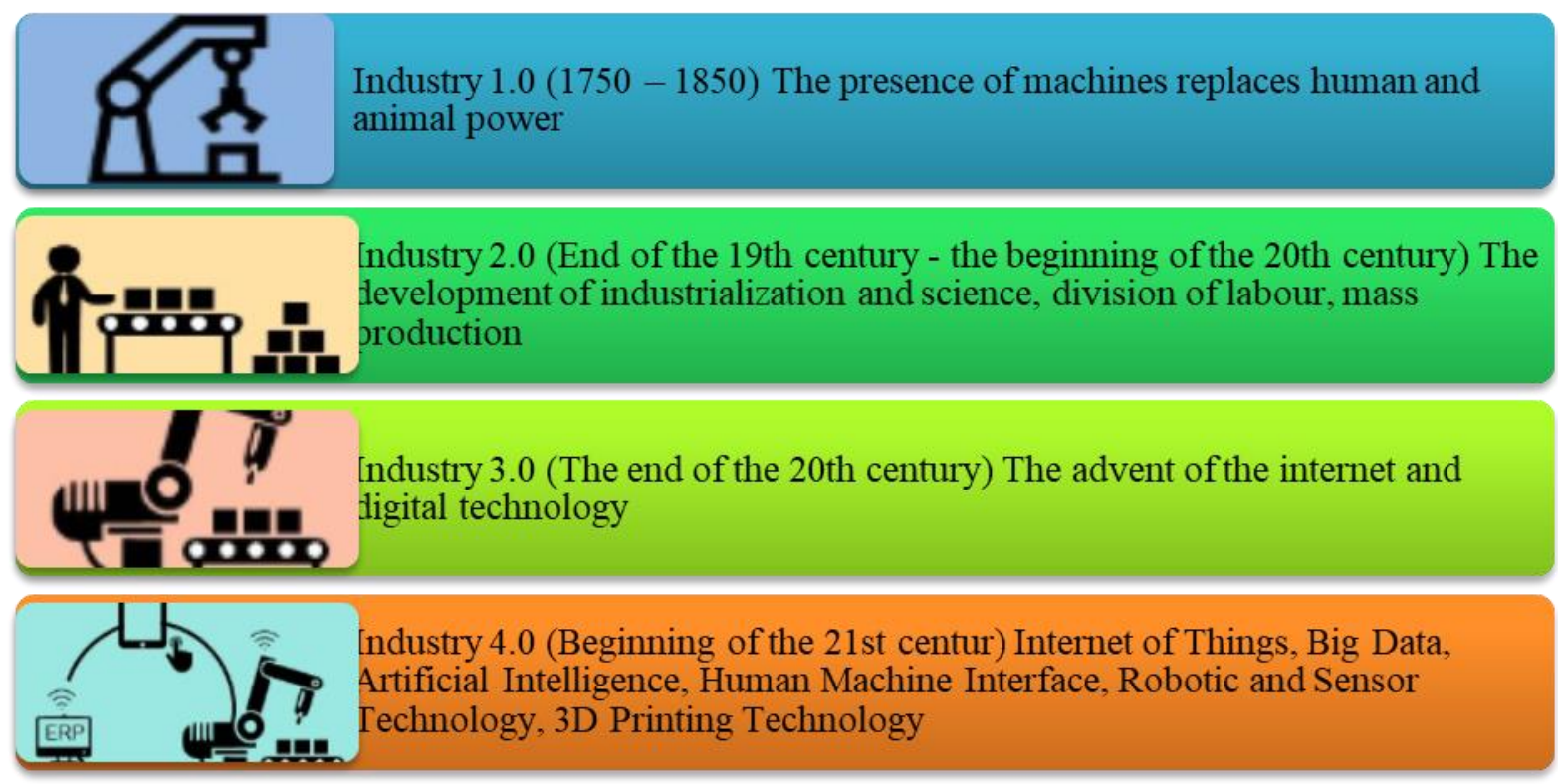

The industrial revolution 1.0 marked by the invention of the first steam engine that made it easy for humans to work. In addition to muscle, another energy that frequently used is water power and wind power. Habitually, this used in crushing to spin a big manufactory, 
humans regularly practice waterwheels or windmills. The principal problem with these two forces is that we can't use them anywhere. We can barely handle it near waterfalls and in windy areas. The industrial revolution 2.0 is characterized by mass production of good quality through the use of electricity which contains lower production costs. Then the 3.0 industry revolution was characterized by mass adjustments and automated-based manufacturing with the computerization of the Industry 4.0 Revolution which changed industry 3.0 which was characterized by changes in the collaboration of manufacturing intelligence and the internet of things as driving the connectivity of human life.

\section{Figure 2.0: 9 Kinds of Technology That Will Become the Main Pillars in the Development of the Industrial Revolution 4.0}

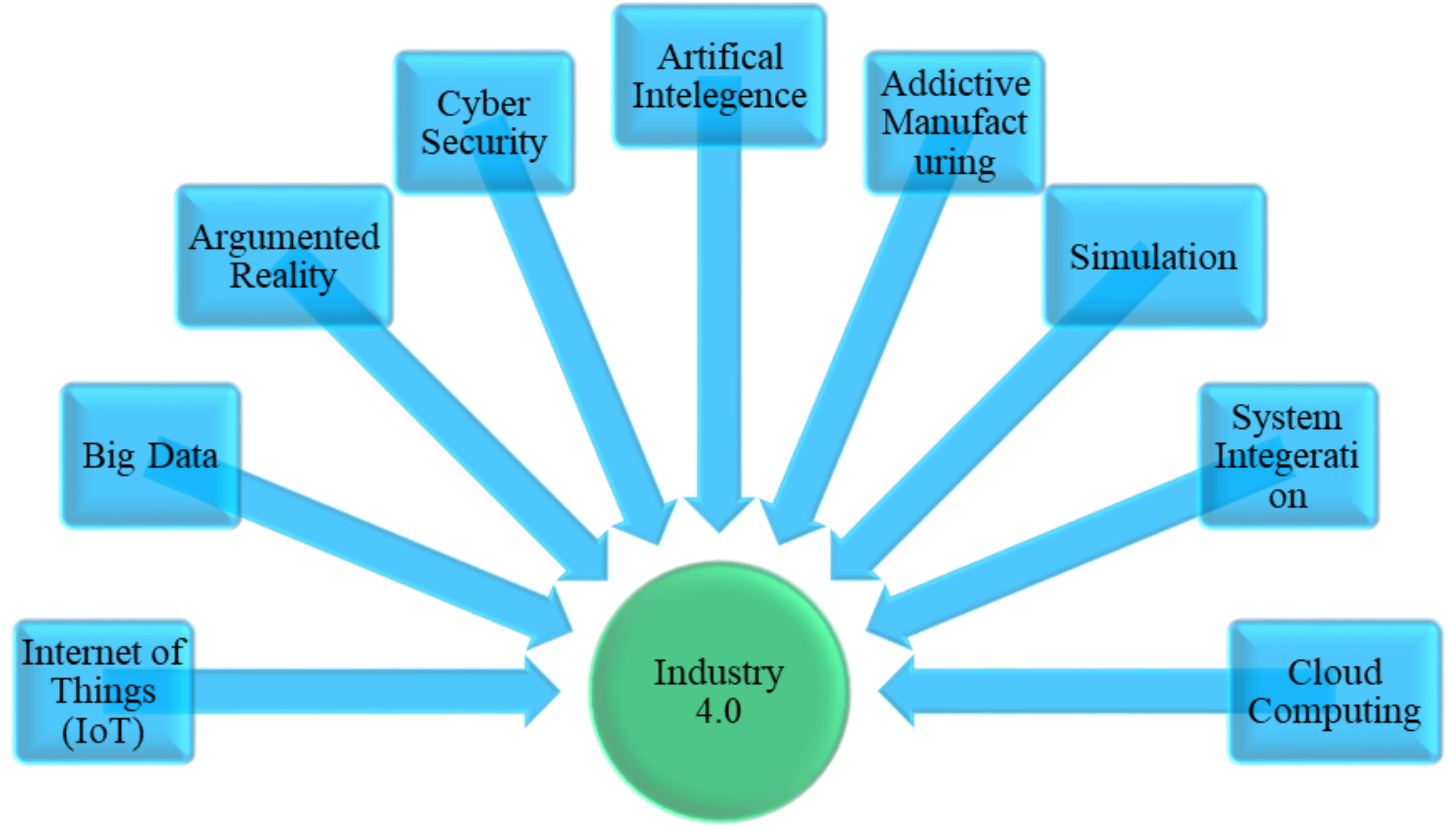

The era of digital banking 4.0 or technological progressions in the Islamic banking industry is an opportunity for banks in Indonesia to be more innovative in providing services to customers. Innovation necessitated responding to competition as the rapid growth of financial technology or fintech. However, the era of digital banking 4.0 also presents several hurdles, such as protecting customer data. Islamic Banking will be affected by splitting from the digital technological age in the 4.0 industrial revolution if it does not respond competently and expeditiously.

The rapid development of the digital banking era in the Islamic banking and Islamic financial sector has changed and disrupted the contemporary business model, if banks have not used this, it will be straightforward to be infringed by fintech. The frequently extensive internet technology not only connects millions of people throughout the world but has also become the base for online trade and transportation transactions. For example, it is an opportunity for Islamic banks in the country to innovate more in providing services to customers. Innovation is needed to respond to competition in involvement with the rapid growth of financial technology. However, on the other hand, the era of digital banking 4.0 also presents some challenges, such as customer data protection. 
Therefore, Islamic Banking demanded to be more adaptive to the development of the era of digital banking 4.0. The development of technology has made the freight industry have to transform and several things that have become the challenge of carrying for the first digital banking, changes in consumption patterns and people's eagerness to get quickly easily. There is a difference in the mode of community behaviour in appropriating the services of financial service institutions - secondary, the increase of financial technology (Fintech) both for payments and funding approximately peer-to-peer lending.

The fundamental principle of the industrial revolution 4.0 is to consolidate machines, workflows and systems by implementing intelligent networks along the production chain and process. That intends to control each other independently. Accelerated technological development insistence encourages changes in people's behaviour; also, an increase in needs will drive changes and the creation of new business and employment opportunities. The development of internet usage drives changes and new business opportunities. Where this opportunity is also realized by business people to utilize the internet in the business process, the use of the internet in the process of doing business will continue to experience growthextending from electronic information exchange to business strategy applications, marketing, sales, to customer service. The internet will also support global communication and cooperation between employees, consumers, sellers and other business partners. Like, among other things, social media technology can be used to create community or family groups in the virtual world. Although geographically far apart but closer to social media. A person's ability to manage knowledge into wisdom in his social environment will circumscribe the level of flexibility in the information age. Hence, the act of sharing information has been based on ethical values so that it will not create an intensification of the public outburst.

Figure 3.0: Fundamental Advantages of Industry 4.0

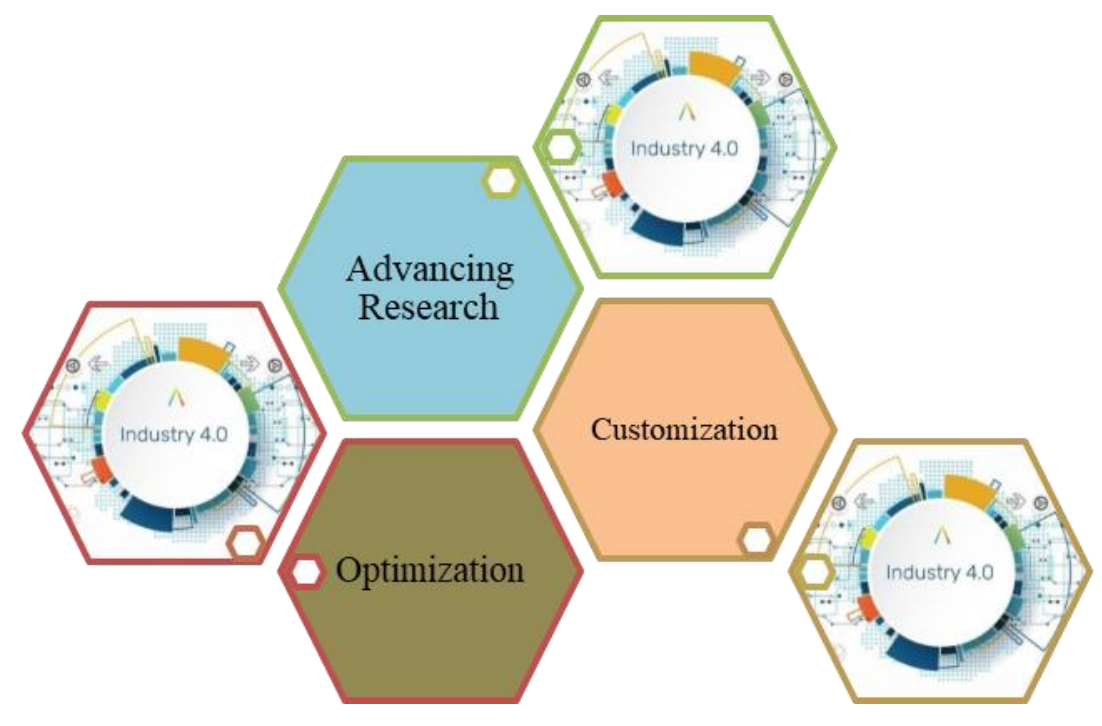

The industrial revolution 4.0, see-through digitalization in various fields that will connect millions of people through the web, thereby increasing business opportunities, business and organizational efficiency, and updating the environment through better asset management. Technology dispensation makes it easier for humans to obtain information 
within digital technology unobstructedly and in a controlled manner. In the future, technological developments insistence establish a new world community, namely the digital age community. To be able to accommodate the changes produced about by the industrial revolution 4.0, a must-have worker skills that cannot be done by machines. One example is the capacity to determine problems or creativity, where soft skills are the primary key. To be able to deal with changes in the coming years, workers demanded who have soft skills such as complex problem solving, critical thinking, creativity, human management, emotional intelligence, judgment and decision making, service-oriented, negotiation, and cognitive flexibility.

Figure 4.0: Challenges Facing Sharia Banking in Era 4.0
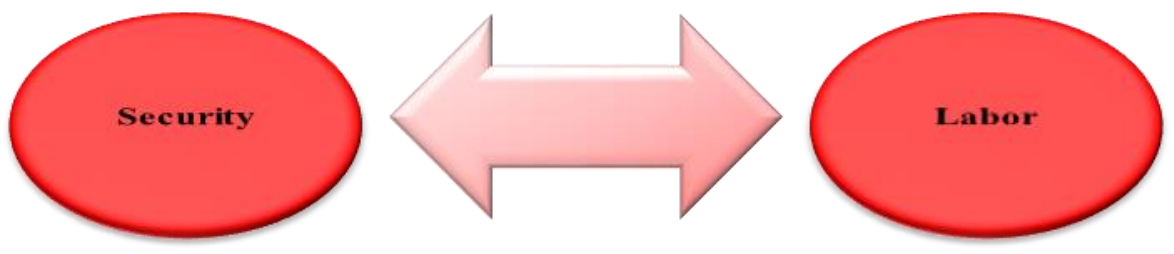

Security is the biggest challenge that industry 4.0 must be adjusted to face. The performance of Cloud Computing has the risk of security holes or security breaches and data leaks. Security breaches and data leaks can cause impairment, despite damage to reliability. Appropriation of industry 4.0 can cause a large amount of human labour to replaced by machinery. That can trigger an increase in unemployment. Therefore education is needed that can support the next generation to be able to fulfil the required skills in Industry 4.0.

SOAR is a strategic planning method based on an Appreciative Inquiry into an engaging offer that is different from existing approaches and techniques. The SOAR pattern transforms the SWOT analysis, which is previously very well established, in terms of organizational internal weaknesses and external threats into the company's aspirations and measurable results that want achieving. That analysis model shows that wants and risks can create negative feelings for members of the organization, thereby diminishing their motivation to do their best.

Figure 5.0: SAR Framework and Shariah 


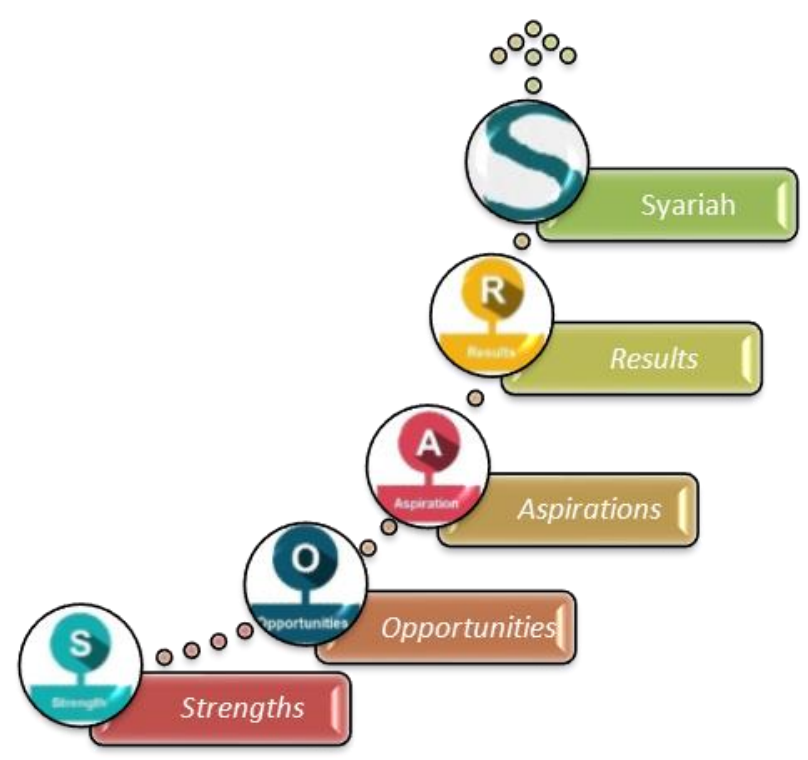

Strengths mean the things that become the strength and the usual essential assets owned disclosed, both tangible assets and intangible assets. Opportunities involve analyzing the visible environment to distinguish the best opportunities that are owned and can be utilized by the organization. Aspirations mean to create a mutually agreed vision, mission and values that guide the organization's journey towards the future. Results involve determining the size of the results to be achieved (measurable results) in strategic planning, to know the extent to which the achievement of objectives that have mutually agreed. Sharia principles are Islamic legal principles in banking activities based on fatwas issued by institutions that have the authority to determine fatwas in the sharia field. Sharia principles are rules of agreement based on Islamic law between banks and other parties for depositing funds and financing business activities, or other activities that declared following sharia. Policy and device to secure the attainment of sharia compliance which is an essential issue in sharia bank regulation. In this connection, the institution that has an important role is the National Sharia Council (DSN) MUI. Law No. 21 of 2008 concerning Sharia Banking grants authority to MUI whose function is carried out by an organ specifically namely DSN-MUI to issue Shariacompliant fatwas of a bank product. 
Figure 6.0: Comparison between SWOT and SOAR

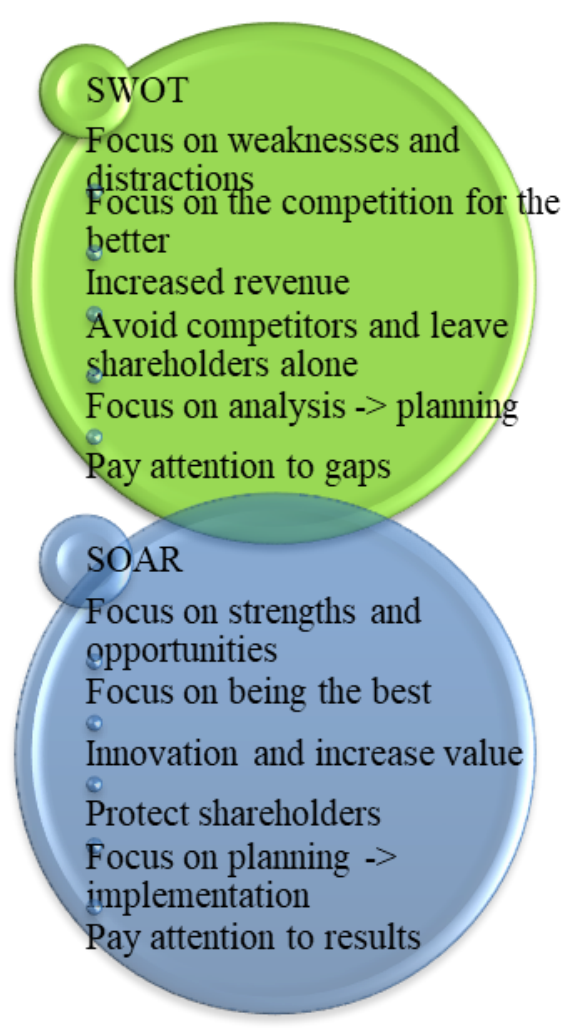

Within the SOAR framework, as many stakeholders as feasible are involved, based on the integrity of its members. The issue of integrity is significant because stakeholders must be aware of the assumptions that are the base of the drivers of the organization's leaders. 
Figure 7.0: SOAR and Sharia Analysis Phase in Sharia Banking in Indonesia in the 4.0 era (Islamic banking products)

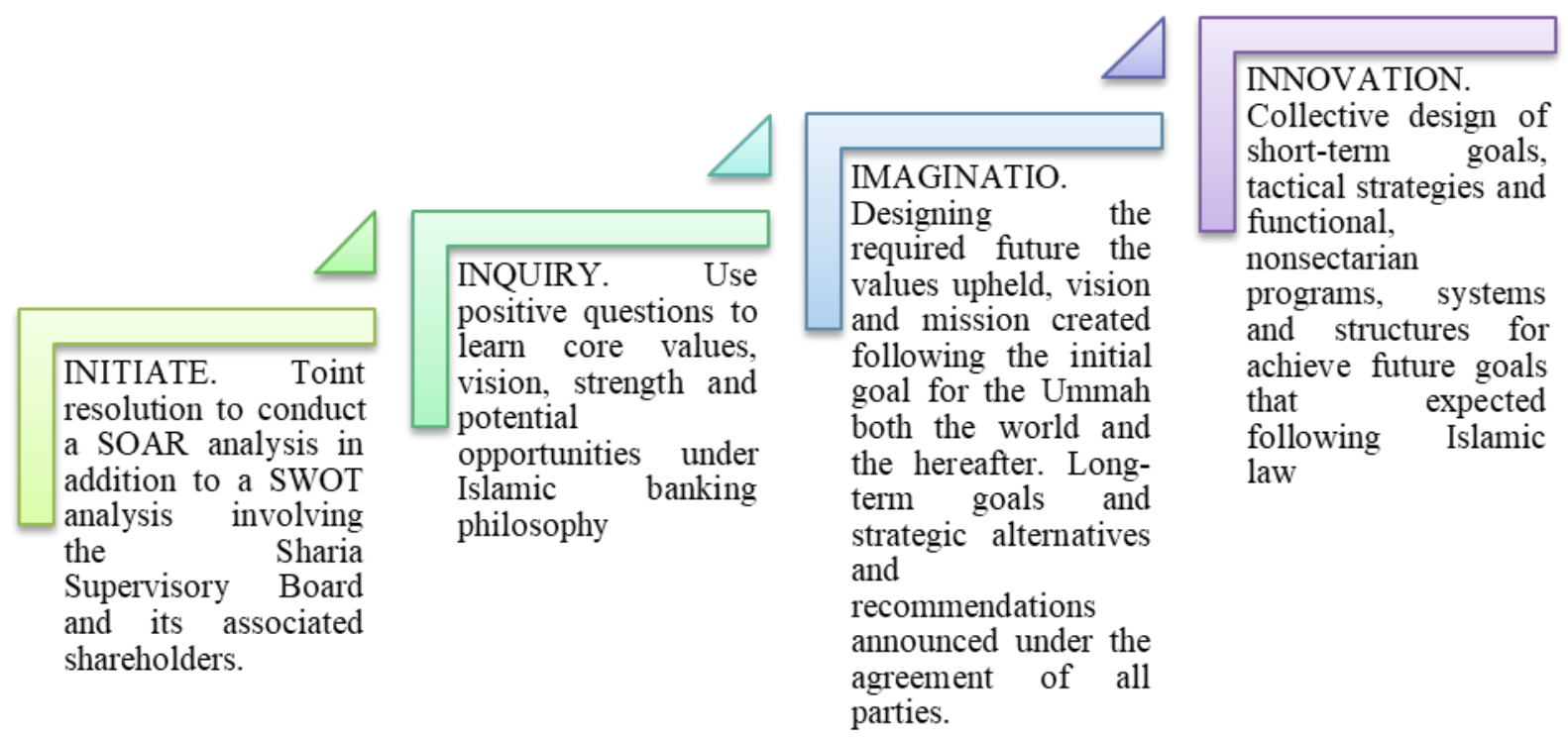

SOAR analysis for the strategic planning of making sharia banking products starts with an initiate (decision to choose SOAR) later continue with an inquiry into whether a product that intended to made is genuinely following sharia. Accordingly, the Sharia Supervisory Board is covered. In this phase, the values of Islamic law reinforced by information from various related parties, the vision and mission of the product created, whether it has a good impact on the benefit of the ummah. Long-term goals and alternative strategies and recommendations to be announced by established regularities. Treatment innovation besides short-term goals, tactical and functional plans, programs, policies, and integrated structures to complete the expected future goals. Investigations additionally carried out to thoroughly understand the Islamic values applied and the contracts used. To achieve the best-restricted results, employees or interested somebody must inspire through a system of recognition and appreciation. Moreover, SOAR always involves stakeholders in determining strategies that will use in business development for the stable future of sharia banking.

Table 1.0: SOAR Matrix

\begin{tabular}{|lll|}
\hline $\begin{array}{l}\text { Internal } \\
\text { External }\end{array}$ & $\begin{array}{l}\text { Strength } \\
\text { List of strength factors } \\
\text { Internal }\end{array}$ & $\begin{array}{l}\text { Oppurtunities } \\
\text { List of external } \\
\text { opportunities }\end{array}$ \\
\hline $\begin{array}{l}\text { Aspiration } \\
\text { List of expected factors } \\
\text { of } \\
\text { Internal }\end{array}$ & $\begin{array}{l}\text { SA Strategy } \\
\text { Create a strategy that } \\
\text { use power to achieve } \\
\text { Aspiration }\end{array}$ & $\begin{array}{l}\text { OA Strategy } \\
\text { Create a strategy that give } \\
\text { orientation to expected } \\
\text { aspirations to utilize }\end{array}$ \\
\hline $\begin{array}{l}\text { Result } \\
\text { List of results }\end{array}$ & $\begin{array}{l}\text { SR Strategy } \\
\text { Create a strategy that }\end{array}$ & $\begin{array}{l}\text { OR strategy } \\
\text { That strategy oriented to }\end{array}$ \\
\hline
\end{tabular}




\begin{tabular}{ll}
$\begin{array}{l}\text { measurable for } \\
\text { manifested }\end{array}$ & $\begin{array}{l}\text { based on strength to achieve chance for achieve vision } \\
\text { Results measured }\end{array}$ \\
\hline
\end{tabular}

The strength of Sharia Banking in Era 4.0 based on SOAR analysis, where I look here in terms of making new products or sharia banking product innovations. The world of digitalization became a vital force in the industrial revolution era 4.0, including the banking industry, including Islamic banking. Technology appropriation for sharia banking believed to be able to drive the progress and development of sharia banking in the country, which is estimated still not optimal compared to its potential. Between the rapid growth of technology and information, technology adoption is now a must for banks. In addition to the fact that the financial services industry has always included in the high-level technology adoption level, it is more because the adoption of technology will transform the company's input structure. Banks that choose more substantial technology will be more efficient in operations. Adoption of technology will advance both the front office and back office.

The technology transformation will support performance, increase efficiency and productivity, which, of course, will help profitability performance. Adoption of digital technology, boosting funds by banks can be more manageable because the public increasingly facilitated to direct banking transaction services and put their funds at the expense of Shariah. One of his strategies, such as the charity auto debit through savings program, is an example of the technology adoption he intended, including the existence of digital banking services for hajj or waqf. The Islamic bank has a cubbyhole market that can be optimized with digital banking facilities, making it more accessible for the public, for example, to pay zakat, infaq and sadaqah. However, with a note, the mechanism and services in digital banking must meet the rules, according to sharia. Including digital transformation, it insistence become a means or media to increase financial literacy. The reason is that digital banking will make it easier for the public to administer financial transactions in Islamic banks, understand sharia products, and make it easier for consumers to make sharia transactions.

Based on SOAR analysis, the next is the opportunity that can use as the strength of Islamic banking in the 4.0 era. To maintain the success of technology-based products that have been developed rapidly throughout the world, a reliable information technology system is needed, and the public can easily access it. Besides easy access, this information system must be able to record the personal information of the people who apply this product to anticipate if somethings not desired, such as dispute resolution can do if the customer makes an achievement wan. The sophistication of information technology is the most dominant thing in the development of digital-based Islamic banking industry. Software technology and big data can use as a risk analyst for potential customers; this is not a difficult thing for technology, because almost everyone has social media that stores their personal data.

Previously, new banking services were only centred in big cities, causing the velocity of money to only be in big cities. By utilizing technology that is rapidly developing now even to the regions, this banking institution can use to spread money circulation to remote areas through its financing products. For example, Islamic banking originated an application for products such as startup companies with mudharabah or qardh contracts. Therefore, despite industry players in the regions can access these products without having to come to the city. Including the easiness of access to these products, it expected that MSMEs in the areas would benefit by, however using Islamic banking services. The next product that can be developed 
by technology-based Islamic banks is Murabahah. Therefore this product will undoubtedly be in demand by many people treasure that e-commerce users in Indonesia are increasing. The instance of this product is Islamic banks in collaboration with e-commerce in Indonesia to use as a medium of online customer/buyer payment through the Islamic bank application. Consequently, the Islamic bank does not need to worry about being left by the customer unless the Islamic bank will be more comprehensive in scope.

As for Aspirations, all can be linked to various inputs and make regulations concerning products that will distribute to the public. Like sharia banking products that have long survived have legal sources and fatwas that have been established by the National Sharia Council-Indonesian Ulema Council (DSN-MUI) beside the requirements of the Financial Services Authority and regulations of each Islamic banking. Subsequent arranging some aspirations about the products to distribute, the DSN-MUI issued a DSN-MUI fatwa, such as for digital products, DSN-MUI has issued different fatwas that support the Islamic banking system. Similar the DSN-MUI fatwa No. 117 / DSN-MUI / II / 2018 concerning Information Technology-Based Financing Services Based on Sharia Principles and DSN-MUI fatwa No. 54 / DSN-MUI / X / 2006 concerning Sharia Cards.

In addition to the DSN-MUI fatwa, Islamic banking has additionally extended regulations with several regulations from BI number 19/12 / PBI / 2017 concerning Financial Technology Implementation OJK Regulation number 13 / POJK.02 / 2018 concerning Digital Financial Innovation in the Financial Services Sector. Bank Indonesia Circular No. 14/17 / DASP concerning Amendments to Bank Indonesia Circular No. 11/10 / DASP regarding the Implementation of Card Instrument Payment Activities and Law No. 19 of 2016 regarding changes to Law No. 11 of 2008 concerning Electronic Information and Transactions.

As a Result of SOAR analysis in Islamic banking, the Financial Services Authority (OJK) documented that in October 2019 financing provided (PYD), Third Party Funds (DPK) and the number of Islamic banking accounts continued to show an advance compared to the end of 2018. The increase occurred along with the extensive use of sharia bank campaigns. OJK recorded the number of accounts in sharia banking reaching 31.89 million as of October 2019. Meantime, the total Third Party Funds (DPK) during the year 2019 reached Rp 402.36 trillion. As of October 2019, there were 165 Sharia Rural Banks (BPRS) in Indonesia. Market share of Islamic banking assets increased to 6.01 per cent compared to September 2019, which reached 5.94 per cent. Then for PYD (Financing Given), it has reached Rp 345.28 trillion, and total assets reached Rp 499.98 trillion. Periodically, year on year, asset growth reaches 10.15 per cent, PYD growth reaches 10.52 per cent, and DPK growth reaches 13.03 per cent. OJK issues POJK Number 28 / POJK.03 / 2019 concerning Banking Synergy in One Ownership for Sharia Banking Development. This rule is an effort to improve the efficiency of the Islamic banking industry for optimization of Commercial Bank resources by Islamic Commercial Banks (BUS) that have control relations. Banking synergy here is a collaboration between Sharia Commercial Banks (BUS) and Commercial Banks that have ownership relationships through optimizing human resources. Information technology and office networks owned by Commercial Banks to strengthen the implementation of Sharia Commercial Banks exercises that contribute added value to Sharia Commercial Banks and Commercial Banks.

During digitalization transactions, PT Bank Syariah Mandiri (BSM) recorded accumulated operations of 52 million as of July 2019, up 18.31 per cent from the previous year period. The number of transactions up collected from registered users of BSM electronic channels, namely ATM, mobile banking and BSM net-banking, amounting to around 4 million Iqtishadia: Jurnal Ekonomi dan Perbankan Syariah 
as of July 2019. PT Bank Syariah Mandiri (Mandiri Syariah) continues to develop fastresponse code payment services with national standards or known as the Quick Response Code Indonesia Standard (QRIS). QRIS payment services can do through Mandiri Syariah Mobile, where the current users of Mandiri Syariah Mobile have reached 1.1 million users. The total Mandiri Syariah Mobile users reached 1.1 million users, with a total of 24 million transactions.

Additionally, BNI Syariah recorded an increase in transactions using mobile banking in March 2020 by $86 \%$ annually or year on year (YoY). That increase is one of them affected by transaction trends that have started to shift to digital and because of the socialization of the use of electronic channel services. Furthermore, the growth of Zakat, Infaq and Sadaqah transaction payments using the mobile banking application increased by $22 \%$ YoY (Annual). Five transaction features are most often used by customers during the February-March 2020 period, including transfers between BNI / BNI Syariah accounts; payment via virtual account; interbank transfer; top-up electronic money balances; and prepaid credit purchases.

Figure 8.0: SOAR and Sharia Analysis Scheme in Sharia Banking Digitalization Products

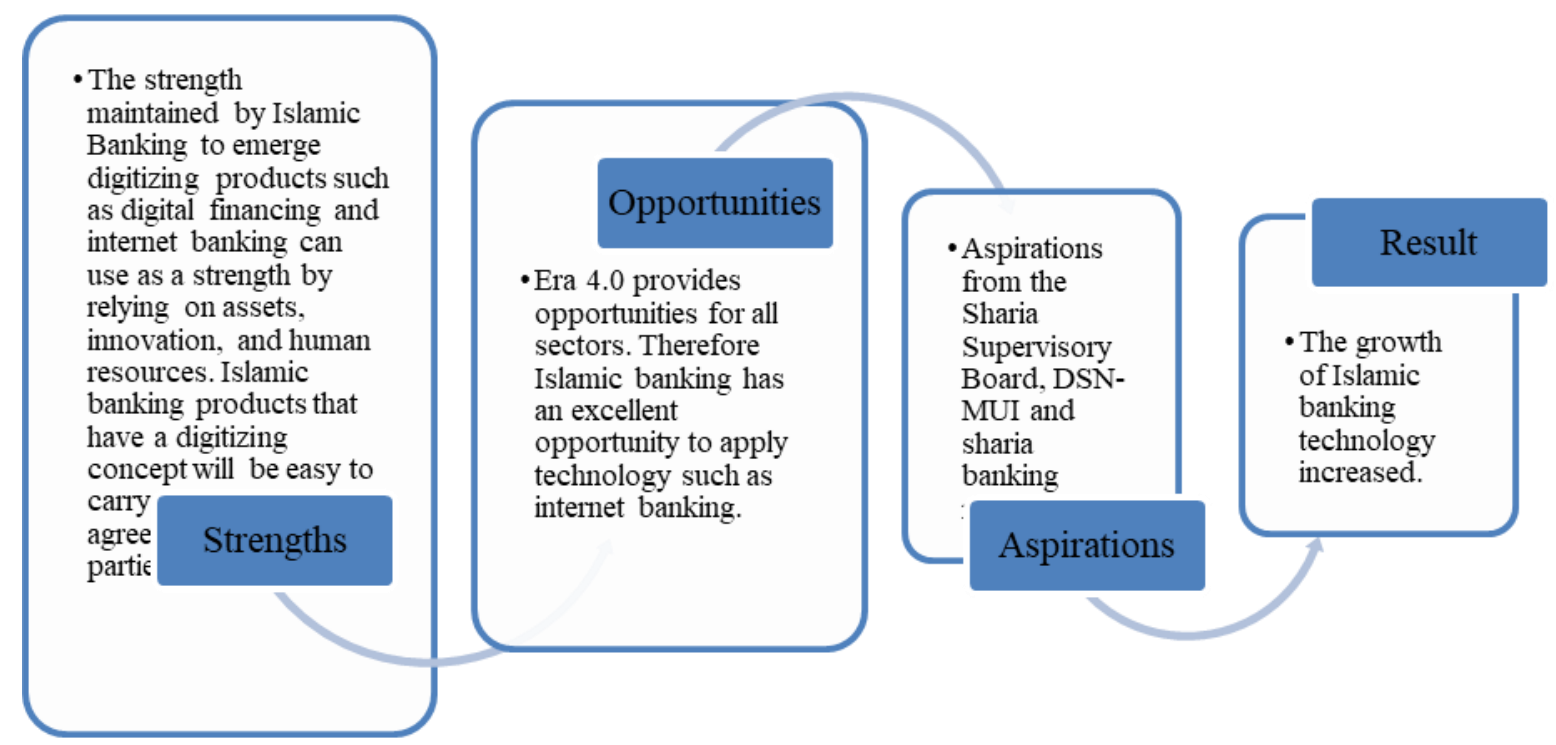

\section{CONCLUSION}

From the above explanation, this can conclude that the 4.0 industrial revolution has had diverse impacts on the world, remarkably in the sharia banking sector which has had many positive effects such as the development of information technology in conducting banking transactions. That is one of the best discoveries and has a reasonably accelerated growth, considering the number of Islamic banking customers in Indonesia is more 
Appreciative Inquiry Analysis Through SOAR Approach In The Lens Of Shariah In Facing Industry 4.0 On Indonesia's Islamic Banking increasing. Through seeing this opportunity, of course, Islamic banking has the possibility and strength to develop the Islamic banking sector further.

\section{REFERENCES}

-_- 2015b. Roadmap Perbankan Syariah 2015-2019. Jakarta: Departemen Perbankan Syariah Otoritas Jasa Keuangan.

_- - 2016. Booklet Perbankan Indonesia 2016. 3rd ed. Jakarta: Departemen Perizinan dan Informasi Perbankan Otoritas Jasa Keuangan.

__- 2017. Modul Keuangan Syariah. Jakarta: Otoritas Jasa Keuangan.

Aam Slamet Rusydiana, "Bagaimana Mengembangkan Industri Fintech Syariah di Indonesia? Pendekatan Interpretive Structural Model (ISM), Jurnal Al- Muzara’ah, Vol 6 No.2 2018

Adrian Teja, "Indonesian Fintech Business: New Innovations or Foster and Collaborate in Business Ecosystems?", The Asian Journal of Technology Management, Vol 10 No 1 (2017)

Antonio, Syafi'I dkk, 2006, Bank Syariah Analisis Kekuatan, Kelemahan, Peluang dan Ancaman, Ekonesia Yogyakarta

Ariani, Nevey Varida. Alternatif Penyelesaian Sengketa Bisnis di Luar Pengadilan.

Eka Satya, Venti. Strategi Indonesia Menghadapi Industri 4.0. Info Singkat. Vol. X, No.

Fatwa DSN-MUI No: 117/DSN-MUI/II/2018 tentang Layanan Pembiayaan Berbasis Teknologi Informasi Berdasarkan Prinsip Syariah

https://www.bnisyariah.co.id/id-id/

https://www.mandirisyariah.co.id/

https://www.ojk.go.id/id/kanal/syariah/data-dan-statistik/statistik-perbankansyariah/Pages/Statistik-Perbankan-Syariah---Maret-2020.aspx

Jurnal RechtsVinding Media Pembinaan Hukum Nasional. 1(2), (2012).

Masulah, Siti. 2014. "Strategi Pengembangan Perbankan Syariah Di Indonesia." Jurnal Akuntansi UNESA 2 (2).

Mervyn K Lewis ,Latifa M.Algaound,2001 Perbankan Syariah Prinsip, Praktek dan Prospek, Serambi Jakarta

Otoritas Jasa Keuangan. 2015a. Booklet Perbankan Indonesia 2015. 2nd ed. Jakarta: Departemen Perizinan dan Informasi Perbankan Otoritas Jasa Keuangan. 
Zulfikar

Peraturan BI nomor 19/12/PBI/2017 tentang Penyelenggaraan Teknologi Finansial Peraturan OJK nomor 13/POJK.02/2018 tentang Inovasi Keuangan Digital di Sektor Jasa Keuangan

Surat Edaran Bank Indonesia No. 14/17/DASP tentang Perubahan atas Surat Edaran Bank Indonesia No. 11/10/DASP perihal Penyelenggaraan Kegiatan Alat Pembayaran dengan Menggunakan Kartu

Ulum, Fahrur. 2014. “Inovasi Produk Perbankan Syariah Di Indonesia.” AlQānūn 17 (1): 33-59.

Utama, Satria, and Putri Ega Handini. 2017. "Inovasi Produk Penghimpunan Dana Perbankan Syariah (Studi Kasus Tabungan Arisan BPRS Madina)." In The 5th Urecol Proceeding, 908-19. Yogyakarta: Universitas Ahmad Dahlan.

UU No. 19 Tahun 2016 perihal perubahan atas UU No. 11 Tahun 2008 Tentang Informasi dan Transaksi Elektronik

UU No. 8 tahun 1999 tentang Perlindungan Konsumen

Waluyo, Agus. 2016. "Kepatuhan Bank Syariah Terhadap Fatwa Dewan Syariah Nasional Pasca Transformasi Ke Dalam Hukum Positif." INFERENSI: Jurnal Penelitian Sosial Keagamaan 10 (2): 517-38. https://doi.org/10.18326/infsl3.v10i2.517-538. 